\title{
Congenital Ichthyosis
}

\section{Gadzhimuradov MN*}

Federal State Budgetary General Educational Institution of the Highest Education, Dagestan State Medical University, Makhachkala city, Russia

Submission: August 23, 2018; Published: September 26, 2018

*Corresponding author: Gadzhimuradov M N, Federal State Budgetary General Educational Institution of the Highest Education, Dagestan State Medical University, Ministry of Health of the Russian Federation, Makhachkala city, Russia, Email: gabenu@mail.ru

\section{Abstract}

\section{What's already known about this topic?}

a) The disease usually occurs in consanguineous marriages.

b) Genetic defect in a skin disease is also accompanied by a rapid growth of hair and nails, deformation and thickening of a nail plate, subungual hyperkeratosis, palmoplantar keratoderma, ectropion and lips, and sometimes mental retardation.

c) Genetic counseling before entering into marriage is the prevention of it.

\section{What does this study add?}

In the family with non-blood related marriage there are a child with lamellar ichthyosis and three cases of stillbirth.

Genetic defect in this skin disease is also accompanied by disorders of gastrointestinal tract, an allergic condition of body, high levels of $\mathrm{C}$-reactive protein and the total of IgE, the defeat of internal organs which determine the severity of state.

A suggestion of research was made to study the factors causing a gene mutation.

\section{Summary}

The article describes the own observation of lamellar ichthyosis - a child aged 14 months, was born from the 8-th pregnancy. It is noteworthy that out of 8 pregnancies mother has 3 stillbirths ( 2 boys, 1 girl), 1 miscarriage in the 2nd month of pregnancy, 2 medical abortion. Two surviving children are a girl of 14 years (health), and the boy. The patient was diagnosed with pathology of gastrointestinal tract, an allergic condition of body, high rates of $\mathrm{C}$-reactive protein and the total of IgE, the defeat of internal organs which determine the severity of his condition. The literature indicated mainly in skin lesions in this disease, and sometimes mental retardation, and it occurs in consanguineous marriages. Considering that the parents of a sick child are not related to each other, it can be assumed that the mutation occurred during intrauterine development. Considering that this family has three cases of stillbirth it is necessary to examine mutagenic factors causing a gene defect. It is necessary to take into consideration the fact that none of family members of this family have been recorded by such a skin disease and by the fact of stillbirth before.

Keywords: Lamellar ichthyosis; Cases from practice; Photophobia; Keratitis

\section{Introduction}

There are many forms of ichthyosis, and in 2009 in the framework of the 1st Consensus Conference on the Ichthyosis (Sorez city, France), approved the unified classification and terminology of ichthyosis. The group of autosomal recessive congenital ichthyosis includes lamellar ichthyosis [1,2]. 8 known genes coding for these violations: ABCA-12, ALOX12B, ALOXE3, CERS3, CYP4F22, NIPAL4, PNPLA1, TGM1. Approximately half of the gene mutation of transglutaminase-1 (TGM1), which is involved in the formation of corneocytes shell leads to the development of lamellar ichthyosis [3]; one of the loci - 14q11. The disease usually occurs in consanguineous marriages. Defeat captures all skin folds in which the process is more pronounced. Hair and nails grow fast, nail plates are deformed, thickened, typical subungual hyperkeratosis, keratoderma of palms and soles. There are lip and eyelids eversion, which promotes the development of infections and, as a consequence, lagophthalmos, keratitis, photophobia. Sometimes mental retardation $[1,4,5]$ is observed in lamellar ichthyosis.

Here is our observation of clinical cases of lamellar ichthyosis. The child is a male aged 14 months enrolled in a skin clinic with complaints of peeling and dryness of the skin. The child was born from the 8-th pregnancy. Parents are not related to each other. It is noteworthy that out of 8 pregnancies mother has 3 stillbirths ( 2 boys, 1 girl), 1 miscarriage in the 2nd month of pregnancy, 2 medical abortion. The two surviving children are a girl of 14 years (health), and the boy.

\section{From history}

Fifth births in 37 weeks, the amniotic fluid with a meager bright yellow grease. On the 4-th day transferred from the maternity hospital to the children's hospital. 


\section{Objectively}

A serious condition; cutaneous covering hyperemic, with marble, the subcutaneous layer is sealed, imposing remains of the colloidal film; on the skin of cheeks, thighs, areas of the epidermis peeling irregular shapes. Eating is enough.

\section{Respiration is puerile, it is over all lung fields, the num- ber of respiratory movements}

42 per minute, pulse - 138 per minute. The abdomen is soft. The liver protrudes from under the costal arch in $1 \mathrm{~cm}$. The spleen is not palpable.

\section{Genitals}

Male, the testes in the scrotum does not clearly palpable.

\section{Neurological status}

Movement are shackled; reaction to the inspection is excessive and negative. Scream is painful. The head is rounded, cranial sutures are closed, large fontanelle is not strained $(1,5 \times 1,5 \mathrm{~cm})$.

\section{Examination}

\section{Neurosonography}

Structural brain is tissue; periventricular region is of slightly increased echogenicity. Flow rate via a vein of Galen is $7 \mathrm{~cm} / \mathrm{s}$. Lateral ventricles: left is $1-1,5-5 \mathrm{~mm}$, right is $1-1-7 \mathrm{~mm}$. The third ventricle is $2 \mathrm{~mm}$.

\section{Echocardiography}

Heart ejection fraction is $75 \%$. Diastolic dysfunction of the right ventricle with moderate tricuspid valve insufficiency.

a) Chest X-ray - pulmonary atelectasis.

b) Ultrasound examination of the abdominal cavity - the left kidney - cups to $9 \mathrm{~mm}$, pelvis is $10 * 8 \mathrm{~mm}$, right pelvis is $9 * 5 \mathrm{~mm}$.

Sowing from skin gave rise to Staphylococcus aureus, Klebsiella pneumoniae Blood cultures is sterile.

Procalcitonin test to $0.5 \mathrm{ng} / \mathrm{ml}$.

Alanine aminotransferase is $1 \mathrm{U} / \mathrm{l}$, aspartate aminotransferase $21 \mathrm{U} / \mathrm{L}$. Total protein is $47-48 \mathrm{~g} / \mathrm{l}$; in the general analysis of blood lymphocytosis and neytrofillez.

Consulting of an ophthalmologist - allergic dermatitis of eyelids, of a gastroenterologist - a syndrome of malabsorption in the intestines.

The diagnosis of primary: intrauterine infection of generalized form, dysbiosis of gastrointestinal sub compensated. Bilateral outer diffuse otitis. An allergic dermatitis of eyelids.

Main 2: congenital ichthyosis, bullous ichthyosiform erythroderma.

\section{Complications}

Malabsorption in the intestines; postnatal malnutrition is of 2-3 degrees; mild anemia.
Related: posthypoxic neonatal cardiomyopathy with diastolic dysfunction and tricuspid valve insufficiency; pyelectasia left.

\section{Treatment}

\section{Intravenous}

Heparin, glucose-saline solutions, ampisid (9 days), amikacin (8 days), prednisolone, mediflyukan, sulperazon (10 days), pentaglobin №3.

Intramuscularly once introduced antibiotic - aseptic necrosis at the injection site. Intramuscular injections hereinafter are contraindicated!

\section{Inside}

Diflucan, bifidumbakterin, Summamed (10 days) of prednisolone, a polyvalent bacteriophage (12 days), Enterofuril, Creon (6 days).

Locally on the skin a methylene blue $1 \%$ aqueous solution, oily solutions and creams. The patient was discharged in mid and grave condition of the skin, malnutrition. It is recommended to continue inpatient treatment for the syndrome of malabsorption and malnutrition.

\section{Objectively}

lagging behind in physical development (in weight almost does not add), seen crying loudly. The vision is normal. The thyroid gland is not increased. Palpable obligate group of lymph nodes - not enlarged, painless, not soldered, mobile. Heart: rhythmic tones, clear, sonorous, the correct ratio. Breathing puerile, carried out in all parts of the lungs, wheezing does not listen. Belly is of regular shape, a bit swollen, symmetrical, painless, soft, available deep palpation. The liver appears in $1 \mathrm{~cm}$. from under the costal arch. Regular chair, decorated, without pathological impurities. Urine output is sufficient. External genitalia are formed correctly (for izoseksual type).

\section{Status specialis}

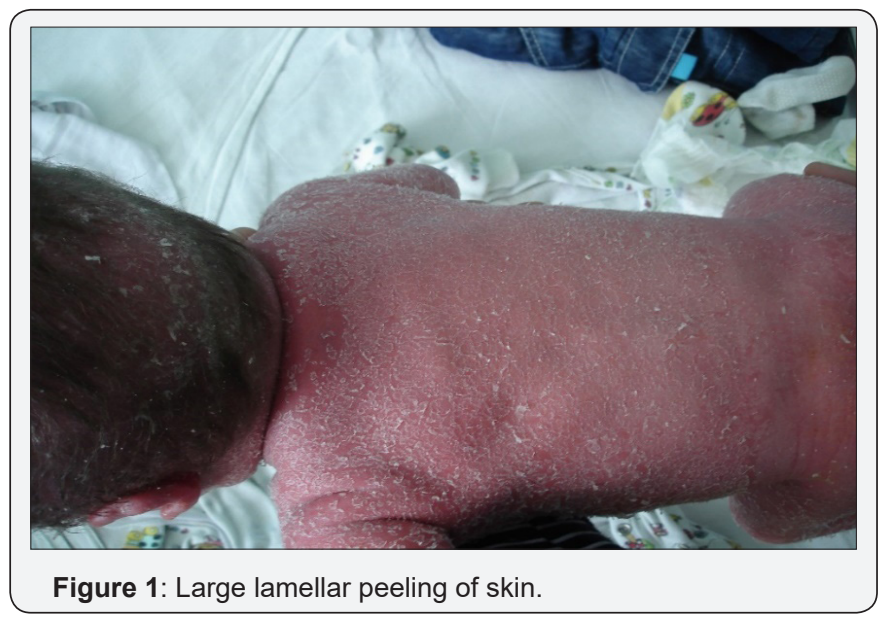

Lesions of a skin is diffuse in the form of vivid hyperemia, infiltration, large and lamellar peeling over the entire surface of the skin (Figure 1), including the folds. Face is mask-like, mucous 


\section{Juniper Online Journal of Dermatology \& Cosmetics}

of eyelids turned inside out (ectropion), dehiscence of mouth, There is some infiltration and swelling of fingers and toes (Figure radial furrows in the perioral area, deformed ears (Figure 2). 3\&4).
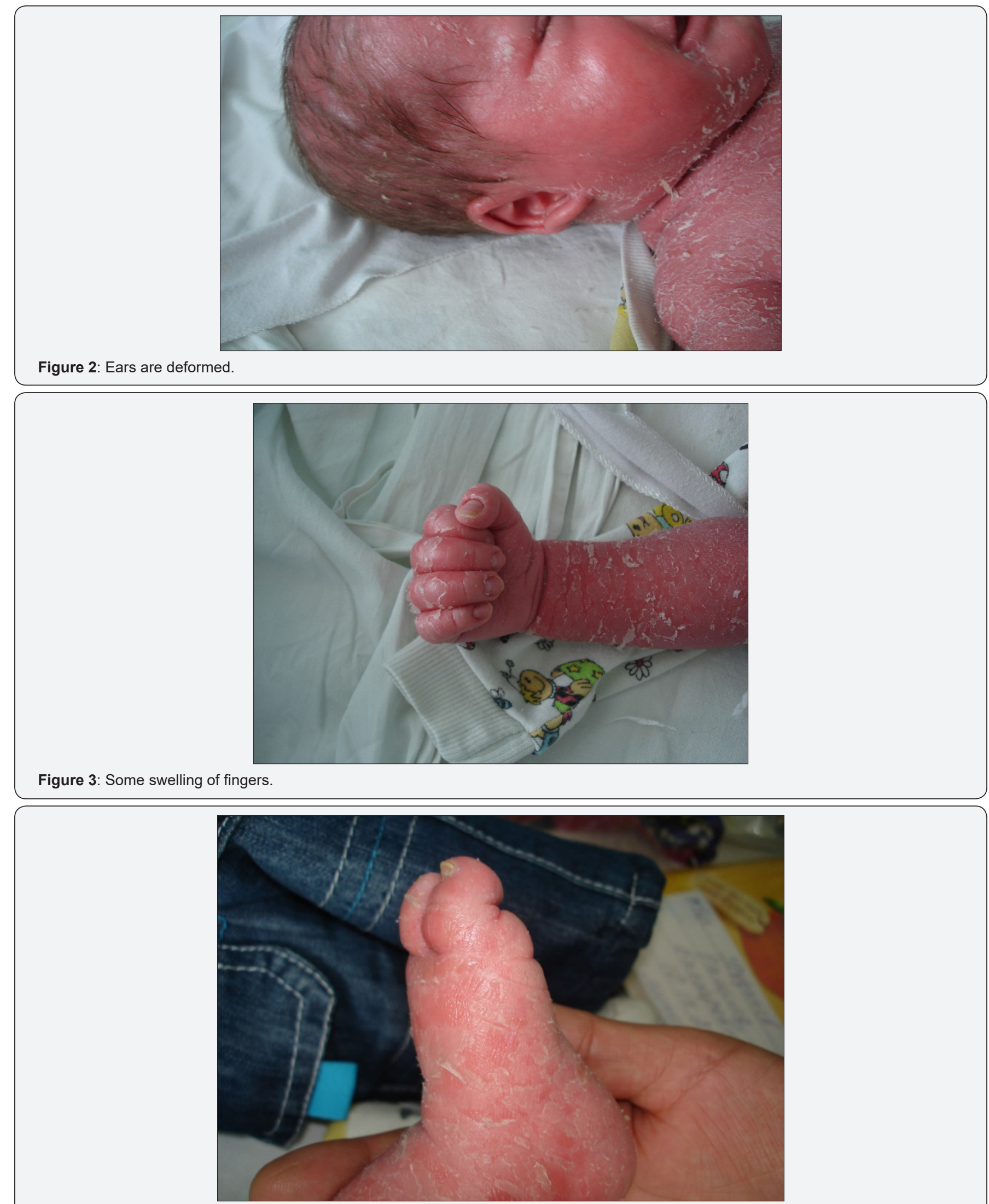

Figure 4: Some swelling of toes. 


\section{Laboratory data complete blood count}

Hb-108g/l, er.-4,05.1012/l tromb.- 482,109/L, LS-7,5.109/L, P.- $0 \%$, SV-42\%, e. - 2\% 0\% B.- lymphocytes - 50\% monocytes - 6\%. Urinalysis is normal. Biochemical analysis of blood: glucose $-7.17 \mathrm{mmol} / \mathrm{L}$, Alanine aminotransferase and aspartate aminotransferase. - OK, C-reactive protein -25.0mg/l (normal 0.00 -up to 5,80), IgE-total 131.99IU/mL (normal 0.00 -up to 22.80). Thyroxine (T4) free - 13.3pmol/l thyrotropin (TSH) - 5.83mU/L.

\section{Ultrasonography (ultrasound) of the internal organs}

Spleen signs of additional shares, pyelitis-calycectasis left, hyperechoic parenchyma of the lower pole.

\section{Otolaryngologist}

Rhinitis, protracted course, carriage of pathogens.

\section{Neurologist}

Perinatal central nervous system of mixed origin, hydrocephalic syndrome.

\section{Recommended}

NSG, ophthalmologist, consultation neyrohyuurga, exercise, Pantogamum syrup.

a) Ophthalmologist: conjunctivitis symptoms have not been identified; fundus without disease, macular reflex is pronounced.

b) Neurosonography: asymmetry of lateral ventricles.

c) Neurosurgeon: Information for Increased intracranial pressure is not obtained. There are not compelling indications for neurosurgical intervention.

d) Pulmonologist: at the time of inspection there was not pathology of the respiratory disease. In attacks of difficulty breathing - inhalation beroduala 7 drops $3 \mathrm{t} / \mathrm{d}$, Pulmicort $250 \mathrm{mcg} 2 \mathrm{t} / \mathrm{d}$, mucolytic Lasolvan 7.5mg (1mL) 2 times /day.

e) Ultrasound of the heart: the pathology is not revealed.

f) Consultation of gastroenterologist: aggregate data we can talk about the presence of immunodeficiency.

g) Clinical diagnosis: lamellar ichthyosis.

h) Treatment: prednisone $1 \mathrm{mg}$ per $1 \mathrm{~kg}$ of body weight with gradual withdrawal, lendatsin $400 \mathrm{mg}$ intravenously №7, asparkam $21 / 3$ tablet twice a day, retinol acetate 1 capsule 1 once a day for kreon $1 / 2$ tablet 1 per day bifiform 1 capsule 2 times a day, Suprastinum on $1 / 4$ tablet 2 once daily, Pantogamum by $1 / 43$ times a day, Otofa 3 drops zykapyvat ear 3 times a day, podideksa spray into the nasal passages injected 3 times per day .

\section{Conclusion}

$\mathrm{He}$ is discharged in a satisfactory condition with an improvement of the skin process. As can be seen from the description of the disease a genetic defect in this skin disease is also accompanied by disorders of the gastrointestinal tract, allergic condition of the body, high levels of C-reactive protein and the total of IgE, visceral, which determine the severity of the condition.

Given that the parents of a sick child are not related to each other, it can be assumed that the mutation occurred during fetal development. In this family, three cases of stillbirth, and therefore it is necessary to study the mutagenic factors causing gene defect. In attention it is necessary to accept the fact that none of the family members of this family have been recorded like skin disease and the fact that stillbirth.

Considering that the parents of a sick child are not related to each other, it can be assumed that the mutation occurred during intrauterine development. This family has three cases of stillbirth as well that's why it is necessary to examine mutagenic factors causing a gene defect. It is necessary to take into consideration the fact that none of family members of this family have been recorded by such a skin disease and by the fact of stillbirth before.

\section{References}

1. Adaskevich V P (2005) Clinical forms and methods of treatment of ichthyosiform dermatoses. Medical News 5: 4-9.

2. Oji V, Tadini G, Akiyama M, Bardon BC, Bodemer C, et al. (2010) Revised nomenklature and classification of inherited ichthyosis: results of the First Ichthyosis Consensus Conference in Soreze 2009. J Am Acad Dermatol 63(4): 607-641.

3. Koshkin SV, Chermnykh TV, Yevseyev AL (2016) Lamellar Congenital ichthyosis. West dermatitis and Venus 5: 44-50.

4. Studnitsyna AA (1983) Differential diagnosis of skin diseases. M Medicine: 560.

5. Vaigundan D, Kalmankar Neha V, Krishnappa J, Gowda NY, Kutty AV, et al (2014) A NovelmMutation in the Transglutaminase-1 Gene in an Autosomal Recessive Congenitalmlchthyosisn Patient. Biomed Res Int 2014: 706827. 
Your next submission with Juniper Publishers will reach you the below assets

- Quality Editorial service

- Swift Peer Review

- Reprints availability

- E-prints Service

- Manuscript Podcast for convenient understanding

- Global attainment for your research

- Manuscript accessibility in different formats

( Pdf, E-pub, Full Text, Audio)

- Unceasing customer service

Track the below URL for one-step submission https://juniperpublishers.com/online-submission.php 